\title{
Host Cell Calpains Can Cleave Structural Proteins from the Enterovirus Polyprotein
}

\author{
Mira Laajala ${ }^{1}\left(\mathbb{D}\right.$, Minna M. Hankaniemi ${ }^{2}$, Juha A. E. Määttä ${ }^{2}$, Vesa P. Hytönen ${ }^{2,3}{ }^{\circledR}$, \\ Olli H. Laitinen ${ }^{2} \mathbb{D}$ and Varpu Marjomäki ${ }^{1, * \mathbb{D}}$ \\ 1 Department of Biological and Environmental Science/Nanoscience Center, University of Jyväskylä, \\ Survontie 9C, FI-40500 Jyväskylä, Finland; mira.a.laajala@jyu.fi \\ 2 Faculty of Medicine and Health Technology, Tampere University, FI-33014 Tampere, Finland; \\ minna.hankaniemi@tuni.fi (M.M.H.); juha.maatta@tuni.fi (J.A.E.M.); vesa.hytonen@tuni.fi (V.P.H.); \\ olli.laitinen@tuni.fi (O.H.L.) \\ 3 Department of Clinical Chemistry, Fimlab Laboratories, Pirkanmaa Hospital District, \\ FI-33520 Tampere, Finland \\ * Correspondence: varpu.s.marjomaki@jyu.fi; Tel.: +358 405634422
}

Received: 8 November 2019; Accepted: 26 November 2019; Published: 28 November 2019

\begin{abstract}
Enteroviruses are small RNA viruses that cause diseases with various symptoms ranging from mild to severe. Enterovirus proteins are translated as a single polyprotein, which is cleaved by viral proteases to release capsid and nonstructural proteins. Here, we show that also cellular calpains have a potential role in the processing of the enteroviral polyprotein. Using purified calpains 1 and 2 in an in vitro assay, we show that addition of calpains leads to an increase in the release of VP1 and VP3 capsid proteins from P1 of enterovirus B species, detected by western blotting. This was prevented with a calpain inhibitor and was dependent on optimal calcium concentration, especially for calpain 2. In addition, calpain cleavage at the VP3-VP1 interface was supported by a competition assay using a peptide containing the VP3-VP1 cleavage site. Moreover, a mass spectrometry analysis showed that calpains can cleave this same peptide at the VP3-VP1 interface, the cutting site being two amino acids aside from 3C's cutting site. Furthermore, we show that calpains cannot cleave between $\mathrm{P} 1$ and 2A. In conclusion, we show that cellular proteases, calpains, can cleave structural proteins from enterovirus polyprotein in vitro. Whether they assist polyprotein processing in infected cells remains to be shown.
\end{abstract}

Keywords: enterovirus; calpain; proteolytic processing; RNA virus; polyprotein

\section{Introduction}

Enteroviruses belong to a large family on non-enveloped RNA-viruses Picornaviridae. Enteroviruses cause diverse diseases in humans with symptoms varying from mild, such as common cold, to more severe such as meningitis, encephalitis, and myocarditis [1-4]. In addition to acute diseases, enteroviruses have been associated with chronic diseases like type I diabetes or asthma [5-7]. However, there is no antiviral on the market against enteroviruses. Our previous studies have shown that host cell proteases, calpains, have a role in enterovirus infection after entry and RNA release and that calpain activity increased during infection at around $3 \mathrm{~h}$ post infection (p.i.), when translation/replication starts to accelerate [8,9].

Enteroviruses are small viruses with single-stranded positive-sense $7500 \mathrm{nt}$ RNA genome inside an icosahedral capsid. After cell entry, the viral RNA is released into the host cytoplasm, where it is directly translated to a single polyprotein and acts as a template in RNA synthesis. The four structural proteins (VP1-VP4) are encoded by P1 region in the polyprotein, whereas P2 and P3 regions contain several nonstructural viral proteins that either directly participate in viral replication or remodel the host 
cell architecture to promote the viral replication [10]. According to current knowledge, the polyprotein is considered to contain all the necessary proteins needed for polyprotein processing as the nonstructural proteins also include viral proteases $2 \mathrm{~A}$ and $3 \mathrm{C}$ and a precursor protein $3 \mathrm{CD}$. These viral proteases have been shown to cleave the polyprotein co- and posttranslationally in order to release the individual proteins [11]. The viral protease 2A is located immediately after the P1 region and has been shown to carry out the first cleavage of itself and the rest of the polyproteins (P2-P3) out from the P1 region already during translation [10-13]. In addition, in trans-polyprotein cleavage by 2A has been reported [14]. The other cleavages, with the exception of capsid maturation cleavage VP0 to VP4 and VP2, have been shown to be carried out either by $3 \mathrm{C}$ or $3 \mathrm{CD}$ precursor, which are located in the $\mathrm{P} 3$ region $[11,15]$. In addition to the polyprotein cleavage, the viral proteases have been shown to cleave several host cell proteins in order to promote infection and to contribute the pathogenicity [10]. The identified cell targets include, for example, proteins involved in cellular transcription, translation, and immune responses [10,16]. The viral proteases $2 \mathrm{~A}$ and $3 \mathrm{C}$ have cysteine in their catalytically active site, being structurally similar to chymotrypsin-like serine proteases [17]. Inside the enterovirus genus, the catalytic cysteine of these proteases and other amino acids in the catalytic triad are fully conserved [10].

Calpains are papain-like cysteine proteases found in almost all eukaryotes [18]. There are 15 different calpains in humans, and the first identified was the conventional calpains 1 and 2 . To form a functional protease, the catalytic subunit $(80 \mathrm{kDa})$ of calpain 1 and 2 form a heterodimer with a regulatory subunit CAPNS1 (30 kDa), which is common to both conventional calpains [18]. Calpains exist in the cytoplasm as proenzymes and are activated when intracellular $\mathrm{Ca}^{2+}$ levels are increased. Instead of complete degradation, calpains cause limited proteolysis mainly in the inter-domain unstructured regions of their substrates. It has been suggested that this is due to a narrow and deep active site in the CysPc protease domain [19]. In order to fit into the active-site cleft, the substrate proteins have to be in an extended conformation. Several protein targets have been found for calpains in in vitro studies such as cytoskeletal proteins, membrane associated proteins, transcriptional factors, as well as kinases and phosphatases $[9,20]$. However, the substrate specificity of calpains has long been unclear, and it has been suggested that the 3D structure of the target protein may play more important role in substrate recognition compared to amino acid sequence of the target [21,22].

Calpains have been associated with enterovirus infection already in earlier studies: they have been suggested to have a role in coxsackie B virus-induced vesicle trafficking inside cells, necrosis, and autophagy [23-25]. Despite earlier studies by us and others, mechanistic understanding of calpain action during the replication/translation phase of enterovirus infection has remained unclear. In addition, the involvement of host cell proteases to take part in proteolytic processing has remained a possibility, but none have been proven so far. Here, we show that calpains are able to proteolytically process the enteroviral P1 region of enterovirus B species at two specific sites in vitro, thus suggesting that they may contribute to efficient capsid maturation of enteroviruses.

\section{Methods}

\subsection{Reagents}

Purified calpain 1 (human) and 2 (rat) proteases were from Calbiochem. Purified viral proteases 2A and 3C were expressed in E. coli as described before [26]. Calpain inhibitor I (N-AcetylLeu-Leu-norleucinal) was from Roche (Basel, Switzerland). Elastatinal was from Santa Cruz biotechnology (Dallas, Texas, USA). Acetonitrile (ACN), formic acid (FA), water (UHPLC-MS grade), triethylammonium bicarbonate buffer $1 \mathrm{M}$ (TEAB), sodium dodecyl sulfate (SDS), iodoacetamide (IAA), trifluoroacetic acid (TFA), ammonium bicarbonate (ABC), and urea were all purchased from Sigma Aldrich Corp. (St. Louis, MO, USA). Sample clean up tips (C18) were from Thermo Fisher Scientific (San Jose, CA, USA). A kit (Bio-Rad DC) and bovine serum albumin standard were purchased from Bio-Rad Laboratories Inc. (Hercules, CA, USA), and $30 \mathrm{kDa}$ molecular weight cut-off (MWCO) centrifugal devices were from PALL (Port Washington, NY, USA). 


\subsection{Cells}

Human alveolar basal epithelial A549 cells (ATCC) were cultured at $37^{\circ} \mathrm{C}$ in Dulbecco's modified Eagle's medium (DMEM, Invitrogen, Carlsbad, CA, USA)) containing 10\% fetal bovine serum (Invitrogen), 1\% glutamax (Invitrogen), and 1\% penicillin and streptomycin antibiotics (Invitrogen). Sf9 cells (Invitrogen) were cultured in insect-XPRESS culture medium (Lonza, Basel Switzerland) and maintained in non-humidified incubator at $27^{\circ} \mathrm{C}$, where the culture flask was rocked at $120 \mathrm{rpm}$. The cultures where passaged in mid-log phase between $4 \times 10^{6}-6 \times 10^{6}$ cells/mL with the seeding density of $1 \times 10^{6}$ cells $/ \mathrm{mL}$.

\subsection{Production of $P 1$ and $P 1-2 A^{*}$ Constructs}

Two baculoviral transfer vectors (pOET5) containing expression cassettes under polyhedrin promoter were ordered from GeneArt (Regensburg, Germany). pOET5-CVB1-P1 vector containing expression cassette for CVB1 capsid proteins VP1-4 and pOET5-CVB1-P1-2A $\mathrm{C}_{>\mathrm{A}}$ vector containing expression cassette for CVB1 capsid proteins VP1-4 and 2A protease with cysteine-to-alanine substitution (resulting in the loss of protease function) were utilized. CVB1 field isolate [7] was used as a template for these constructs. The recombinant baculoviruses were produced according to the FlashBAC baculovirus expression system (Oxford Expression Technologies, Oxford, UK). In FlashBAC ULTRA baculovirus genome, the genes coding for chitinase, cathepsin, p10, p26, and p74 are deleted. CVB1-P1 (P1) and CVB1-P1-2A $>$ A $\left(\mathrm{P} 1-2 \mathrm{~A}^{*}\right)$ polyproteins were produced in Sf9 insect cells, the cells containing the polyproteins were harvested 3-6 dpi by centrifugation, and proteins were released from the cells by freezing and thawing the cells.

\subsection{Calpain In Vitro Cleavage Assays}

A reaction mixture containing the following components was prepared: $1.6 \mu \mathrm{g}$ of P1 or P1-2A* containing lysate, $1 \mathrm{U}$ calpain proteases, $2 \mathrm{mM} \mathrm{CaCl}_{2}$, and PBS. In the inhibitor assay, the reaction mixture also contained $200 \mu \mathrm{M}$ calpain inhibitor I or $250 \mu \mathrm{M}$ elastatinal.

In the calpain titration assay, the reaction mixture contained $1.6 \mu \mathrm{g}$ of P1 containing lysate and $0.01 \mathrm{U}, 0.1 \mathrm{U}, 0.5 \mathrm{U}$, or $1 \mathrm{U}$ of calpain proteases in PBS. The mixture also contained $2 \mathrm{mM} \mathrm{CaCl}_{2}$ and $4 \mathrm{mM}$ EGTA when indicated. In the calcium titration assay, the reaction mixture contained $1.6 \mu \mathrm{g}$ of P1 containing lysate; $1 \mathrm{U}$ of calpain proteases; and $0,0.002,0.02,0.2$, or $2 \mathrm{mM} \mathrm{CaCl}_{2}$ in $\mathrm{PBS}$.

The reactions were incubated at $25^{\circ} \mathrm{C}$ in water bath for $2 \mathrm{~h}$. The reactions were terminated by adding $4 \times$ SDS-PAGE sample buffer containing mercaptoethanol ( $1 \times$ final concentration).

\subsection{In Vitro Cleavage Assay with Viral Proteases}

The reaction mixture contained $1.6 \mu \mathrm{g}$ of $\mathrm{P} 1$ or $\mathrm{P} 1-2 \mathrm{~A}^{*}$ containing lysate, $750 \mathrm{ng}$ of purified viral proteases $2 \mathrm{~A}$ or $3 \mathrm{C}$ in buffer containing $20 \mathrm{mM}$ HEPES ( $\mathrm{pH}$ 7.4), $120 \mathrm{mM} \mathrm{KCH} \mathrm{CHOO}_{3}, 4 \mathrm{mM}$ $\mathrm{Mg}\left(\mathrm{CH}_{3} \mathrm{COO}\right)_{2}$, and $5 \mathrm{mM}$ DTT.

In the inhibitor assay, the viral proteases were incubated with A549 cell homogenate, which was prepared as described [27]. The reaction mixture contained $75 \mu \mathrm{g}$ of the homogenate, $375 \mathrm{ng}$ of $2 \mathrm{~A}$ or $3 \mathrm{C}$ with or without $200 \mu \mathrm{M}$ calpain inhibitor I or $250 \mu \mathrm{M}$ elastatinal, and reaction buffer $(20 \mathrm{mM}$ HEPES (pH7.4), $120 \mathrm{mM} \mathrm{KCH} 3 \mathrm{COO}_{4} 4 \mathrm{mM} \mathrm{Mg}\left(\mathrm{CH}_{3} \mathrm{COO}\right)_{2}$, and $5 \mathrm{mM}$ DTT).

The reactions were incubated at room temperature $\left(+22^{\circ} \mathrm{C}\right)$ for $18 \mathrm{~h}$, after which $4 \times$ SDS-PAGE sample buffer containing mercaptoethanol ( $1 \times$ final concentration) was added to terminate the reaction.

\subsection{Infection Assay in Cells}

A549 cells were infected with EV1 (Farouk strain, ATCC), CVB3 (Nancy strain, ATCC), or CVB1 (Conn 5 strain, ATCC) with $2 \times 10^{8} \mathrm{PFU} / \mathrm{mL}$. The viruses were first bound on ice for $1 \mathrm{~h}$ in DMEM supplemented with $1 \%$ fetal bovine serum and $1 \%$ glutamax. Next, excess virus was washed away with PBS, and fresh DMEM supplemented with $1 \%$ fetal bovine serum and $1 \%$ glutamax containing 
$200 \mu \mathrm{M}$ calpain inhibitor I or $250 \mu \mathrm{M}$ elastatinal was added. The infection was then allowed to proceed at $37^{\circ} \mathrm{C}$ for $5.5 \mathrm{~h}$. Finally, the cells were either fixed with $4 \%$ paraformaldehyde for 30 min or collected into $2 \times$ Laemmli buffer containing mercaptoethanol ( $1 \times$ final concentration).

\subsection{Immunofluorescence Labeling and Microscopy}

The cells were permeabilized with $0.2 \%$ Triton X-100 and then treated with primary antibodies: rabbit anti-EV1 [28] for EV1 or monoclonal mouse Enterovirus clone 5-D8/1 antibody (Dako) for CVB3 and CVB1. After $1 \mathrm{~h}$ of incubation, excess primary antibody was washed with PBS and cells were treated with secondary antibodies: goat anti-rabbit Alexa 555 (Invitrogen) or goat anti-mouse Alexa 555 (Invitrogen). Secondary antibody was washed with PBS and nuclei stained with DAPI in PBS. Finally, the cells were mounted into mowiol-DABCO.

Samples were imaged with Olympus FV1000-IX81 confocal microscope using 543-nm HeNe and 405-nm diode lasers. The imaging was carried out with 60× UPLSAPO objective (NA 1.35), and levels for the laser power and detector amplification were optimized using negative infection control.

\subsection{Western Blot}

Samples were first boiled and then run in 4-20\% Miniprotean TGX gradient gel (Bio-Rad Laboratories Inc.). Next, the proteins were transferred to PVDF membrane (Immobilon-P, Merck Millipore; Burlington, MA, USA), after which the blot was blocked overnight with 5\% BSA in $0.05 \%$ tween in TBS. Poly A binding protein (PABP) was detected using 1:100 dilution of mouse anti-PABP (Santa Cruz). Ras GTPase-activating protein-binding protein 1 (G3BP1) was detected using 1:1000 dilution of mouse anti-G3BP1 (Santa Cruz). VP3 was detected using in-house produced rabbit-anti-CVB1-6 polyclonal antibody. VP1, P1, and P1-2A* were detected using 1:4000 dilution of monoclonal mouse enterovirus clone 5-D8/1 antibody (Agilent Dako, Santa Clara, CA, USA). Gamma-tubulin was detected using 1:20,000 dilution of rat anti-tubulin antibody (Abcam, Cambridge, Unitied Kingdom). The primary antibodies were detected using corresponding horseradish peroxidase-conjugated secondary antibodies (cell signaling). Next, chemiluminescent substrate (supersignal West Pico PLUS, Thermo Fisher Scientific, Waltham, MA, USA) was incubated for 5 min and the chemiluminescence was detected using Chemidoc MP (Bio-Rad Laboratories Inc.). In the Figure 2, the total protein amount was revealed using stain-free method by UV-activating the gel with Chemidoc MP (Bio-Rad Laboratories Inc.) before transfer to PVDF membrane. The western blot results were quantified using the gel analyzer tool embedded in Image J.

\subsection{Cleavage Assay with the Peptide}

A 30-amino-acid peptide from CVB1 VP3 and VP1 capsid protein interface (peptide sequence: NH2-MLKDTPFIRQDNFYQ*GPVEESVERAMVRVA-COOH; putative 3C cleavage site indicated by asterisk) was chemically synthesized (Proteogenix, Sciltigheim, France) and treated with calpain 1, calpain 2, and $3 \mathrm{C}$ proteases. Two micrograms of the peptide was incubated in the presence of $0.25 \mathrm{U}$ calpain 1, $0.25 \mathrm{U}$ calpain 2, or $750 \mathrm{ng} 3 \mathrm{C}$ protease. Reactions containing calpain 1 or calpain 2 were incubated two hours in $25^{\circ} \mathrm{C}$ water bath in PBS containing $2 \mathrm{mM} \mathrm{CaCl}_{2} .3 \mathrm{C}$ protease reactions were incubated $20 \mathrm{~h}$ at room temperature in $20 \mathrm{mM}$ Tris pH 7.3, $100 \mathrm{mM} \mathrm{NaCl}$, and $1 \mathrm{mM}$ EDTA.

In the competition assay, a reaction mixture containing the following components was prepared: $1.6 \mu \mathrm{g}$ of P1 containing lysate, $1 \mathrm{U}$ calpain proteases 1 or 2 , or $750 \mathrm{ng}$ of $3 \mathrm{C}$ protease with or without $100 \mu \mathrm{g}$ of the peptide. The calpain reactions were incubated in $25^{\circ} \mathrm{C}$ water bath for $2 \mathrm{~h}$ in PBS containing $2 \mathrm{mM} \mathrm{CaCl}_{2} .3 \mathrm{C}$ protease reactions were incubated for $17 \mathrm{~h}$ at $22^{\circ} \mathrm{C}$ in $50 \mathrm{mM}$ Tris $\mathrm{pH} 7.5$, $150 \mathrm{mM} \mathrm{NaCl}, 1 \mathrm{mM}$ EDTA, and $1 \mathrm{mM}$ DTT. The reactions were terminated by adding $4 \times$ sample buffer containing mercaptoethanol ( $1 \times$ final concentration). 


\subsection{Mass Spectrometry}

Cleavage assay's peptides with or without proteases were analyzed with Eksigent 425 NanoLC coupled with Sciex high speed TripleTOF ${ }^{\mathrm{TM}} 5600+$ mass spectrometer using sequential window acquisition of all theoretical mass spectra (SWATH-MS) proteomics. Prior to SWATH analysis method, a relative protein quantification library was built from several data-dependent analysis (DDA) runs with the same LC gradient and instrument settings that were used for SWATH analyses. Before MS runs, samples were subjected to reduction, alkylation, and digestion with calpain protease instead of trypsin as described in detail in Reference [29]. After digestion, peptides were diluted to $14 \mu \mathrm{l}$ of sample buffer ( $2 \%$ acetonitrile and $0.1 \%$ formic acid) and $1 \mu \mathrm{l}$ of sample was injected to the triple TOF mass spectrometry. Library was created using Protein Pilot 4.7 (Sciex, Redwood City, CA, USA), and all DDA run spectra were identified against coxsackievirus B3 and calpain (human and rat) UniprotKB/SwissProt protein library added with synthetic CVB1 VP3-VP1 peptide. Quantification was done by Peak Viewer and Marker Viewer (Sciex).

\subsection{Statistical Testing}

The statistical analysis was carried out using GraphPad Prism software. (GraphPad Software, San Diego, CA, USA) The data are presented as means \pm SEM. The statistical significance was determined using parametric one-way ANOVA with Bonferroni's multiple comparisons test.

\section{Results}

\subsection{Calpain Inhibitor Prevents the Enterovirus Infection Whereas 2A Inhibitor Does Not}

The effect of calpain inhibitor on the infection of A549 cells with different serotypes of enterovirus B species was tested, and infection was detected by the marked accumulation of VP1 in the cytoplasm by immunofluorescence. The results showed that the presence of $200 \mu \mathrm{M}$ calpain inhibitor strongly reduced the VP1 signal and decreased the number of EV1-, CVB3-, and CVB1-infected cells compared to the control infection (Figure 1A). The input virus used in the infection was seen as bright spots in endosomes, particularly in CVB3 infected cells (Figure 1A). In contrast, the addition of $250 \mu \mathrm{M}$ elastatinal, which has been shown to inhibit 2A [30], did not suppress the infection of A549 cells by any of these viruses (Figure 1A). The same observation was also evident when the levels of VP1 protein were analyzed from the whole cell population using western blotting (Figure 1B).

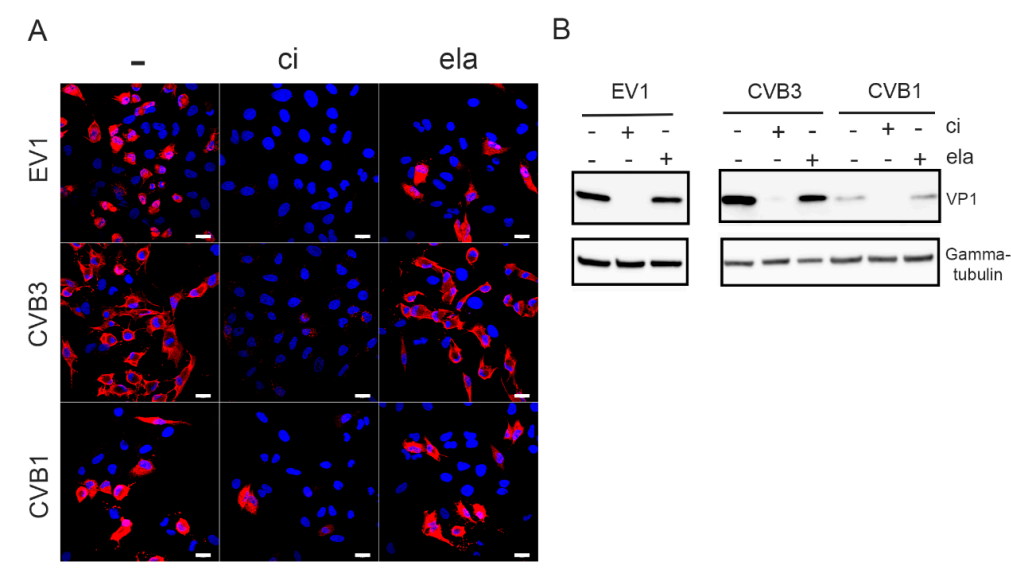

Figure 1. Calpain inhibitor prevents the infection by enteroviruses: A549 cells were infected with EV1, CVB3, or CVB1 for 5.5. h p.i. with or without $200 \mu \mathrm{M}$ calpain inhibitor (ci) or $250 \mu \mathrm{M}$ elastatinal (ela). (A) Immunofluorescence microscopy was used to evaluate the infection. Viral protein VP1 is in red, and DAPI-stained nuclei are in blue. Scale bar $20 \mu \mathrm{M}$. (B) For Western blot analysis, the infected A549 cell lysates were resolved in 4-20\% SDS-PAGE gels, blotted, and immunolabeled with antibodies against VP1 and gamma-tubulin as a loading control. 


\subsection{Calpain Inhibitor Cross-Reacts with Viral Proteases $2 A$ and $3 C$}

Both calpains and viral proteases of enteroviruses have cysteine in their catalytically active site. Because our present and earlier results [8] showed that the enterovirus infection was inhibited by a calpain inhibitor, we also wanted to test whether the inhibitor has an effect on viral proteases. We carried out an in vitro assay, where A549 cell homogenate was incubated with purified viral proteases with or without a calpain inhibitor (Figure 2). The cleavage action of 2A and 3C was evaluated by detecting the known host cell targets of the proteases, poly A binding protein (PABP), and Ras GTPase-activating protein-binding protein 1 (G3BP1). Western blot results showed that the calpain inhibitor prevented the action of both proteases: the amount of PABP protein was in the same level as in controls lacking proteases, and the amount of G3BP1 cleavage product was clearly less in the presence of the inhibitor than without it (Figure 2). In addition, we confirmed that another protease inhibitor, elastatinal, which has been shown to inhibit 2A, inhibited the action of $2 \mathrm{~A}$ but not $3 \mathrm{C}$ (Figure 2.).
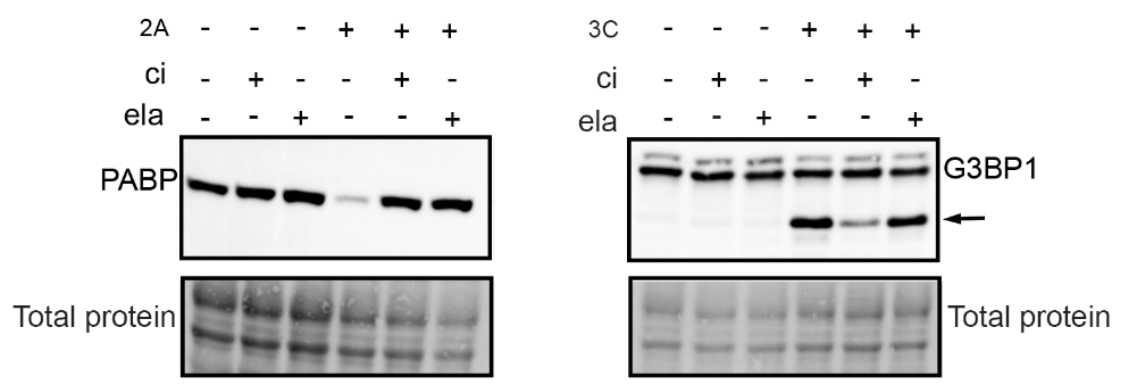

Figure 2. Calpain inhibitor cross-reacts with viral proteases. A549 cell homogenate was incubated with purified viral proteases $2 \mathrm{~A}$ and $3 \mathrm{C}$ in the presence or absence of $200 \mu \mathrm{M}$ calpain inhibitor (ci) or $250 \mu \mathrm{M}$ elastatinal (ela) for $18 \mathrm{~h}$ at $22{ }^{\circ} \mathrm{C}$. Western blot analysis was done by resolving the samples in 4-20\% SDS-PAGE gels and transferring to PVDF membrane. The blots were immunolabeled with PABP and G3BP1 antibodies, and the total protein amount was assessed using a stain-free method. Arrow indicates $3 \mathrm{C}$ protease induced cleavage fragment of G3BP1.

\subsection{Calpains Can Cleave P1 into VP1 and VP3 In Vitro but Cannot Release P1 from the Polyprotein}

Because we noticed that calpain inhibitor also cross-reacts with viral proteases, we wanted to study the action of calpains and viral proteases separately. We used the baculovirus-infected Sf9 insect cells to produce the $\mathrm{P} 1$ region of CVB1 polyprotein (Figure 3A). In addition, since our preliminary study showed that the $2 \mathrm{~A}$ inhibitor elastatinal could not prevent virus infection, we also produced a construct where the $\mathrm{P} 1$ region was followed by mutated 2A (P1-2A*) in order to study the cleavage site between P1 and 2A (Figure 3A). Viral protease 2A cotranslationally cleaves between itself and P1 region [11-13], so in order to avoid this cleavage action by $2 \mathrm{~A}$, the active site cysteine of $2 \mathrm{~A}(\mathrm{C} 110)$ was mutated into alanine.

Purified calpain proteases 1 and 2 as well as viral proteases $2 \mathrm{~A}$ and $3 \mathrm{C}$ were incubated with $\mathrm{P} 1$ or P1-2A* in vitro, after which the cleavage products were detected by western blotting. The results showed that the amount of $\mathrm{P} 1$ and $\mathrm{P} 1-2 \mathrm{~A}^{*}$ decreased in the presence of both calpain 1 and 2 enzymes (Figure 3B,C). More importantly, when the P1 construct was treated with calpains, the cleavage products corresponding to VP1 and VP3 proteins appeared and accumulated compared to the control, where no calpains were added (Figure 3B,D,E). The amounts of both VP1 and VP3 were statistically higher compared to control, when P1 was treated with calpain 2 ( $p<0.01$ and 0.001 for VP1 and VP3, respectively). Also, calpain 1 produced more VP1 and especially VP3 compared to control, but the results were not statistically significant. This result thus suggested that calpain 2 is more potent at cleaving the P1 region in vitro as compared to calpain 1. As we saw, a low background signal of VP1 in the insect cell produced a P1-containing sample; we tested whether this may be due to a low activity of endogenous proteases, perhaps close to mammalian calpains. Addition of the calpain inhibitor after 
day 1 in the infected insect cell culture prevented the accumulation of VP1 band at day 2, suggesting that the inhibitor prevented proteolytic processing carried out by endogenous calpain or a close relative in the insect cells (Mira Laajala, University of Jyväskylä, Finland, Unpublished experiments performed on insect cell cultures). Understandably, we could not add calpain inhibitor in our assays when we assessed the proteolytic processing of exogenously added calpains, which caused the presence of a low endogenous amount of processed VP1 in the assays (Figures 3, 4 and 5B). As a positive control, we used purified viral protease $3 C$, which resulted in a statistically significant increase of released VP1 and VP3 proteins compared to the negative control (Figure 3B,D,E) $(p<0.01$ and 0.001 for VP1 and VP3, respectively). Additionally, our results showed that 2A viral protease cannot cleave at the P1-2A cleavage site in trans, when it is not attached to the polyprotein (Figure 3B,D,E). It was also evident that calpains cannot cleave at this cleavage site, since no cleavage product corresponding to either P1 or VP1 appeared (Figure 3B). Still, calpains were able to release VP3 from P1-2A*, confirming that the sites between VP3-VP1 and VP3-VP0 can be processed by calpains (Figure 3B,E). These results suggest that calpains, similar to $3 \mathrm{C}$, can cleave $\mathrm{P} 1$ polyprotein of enterovirus $\mathrm{B}$ species in vitro and can produce VP1 and VP3 as cleavage products.

A

\begin{tabular}{|c|c|c|c|c|c|c|c|c|c|c|}
\hline \multirow[b]{2}{*}{ Polyprotein } & \multicolumn{3}{|c|}{ Structural (P1) } & \multicolumn{7}{|c|}{ Non-structural (P2-P3) } \\
\hline & VPO & VP3 & VP1 & $2 \mathrm{~A}$ & $2 \mathrm{~B}$ & 20 & $3 \mathrm{~A}$ & $3 B$ & $3 c$ & $3 D$ \\
\hline & VPO & VP3 & VP1 & & & & PO & VP3 & VP & $2 A^{*}$ \\
\hline
\end{tabular}

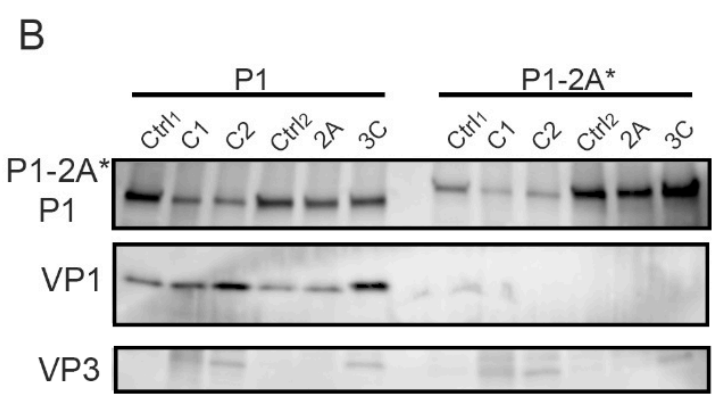

D

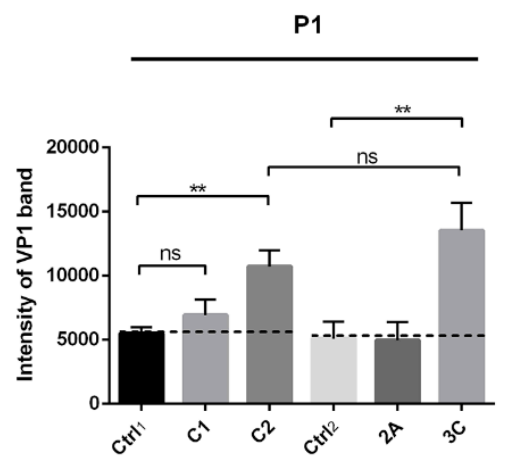

C

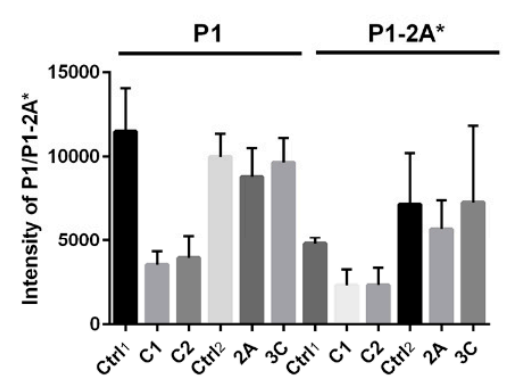

E

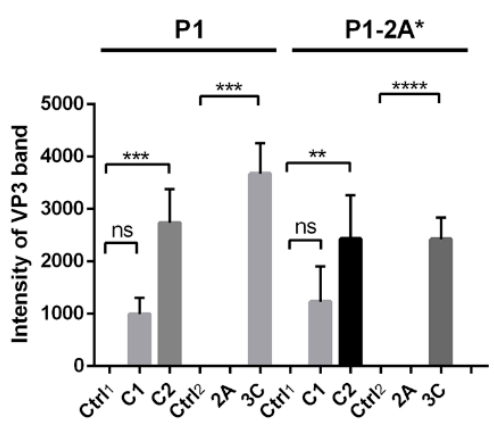


Figure 3. Processing of $\mathrm{P} 1$ and $\mathrm{P} 1-2 \mathrm{~A}^{*}$ constructs by calpains and viral proteases in vitro: $\mathrm{P} 1$ and $\mathrm{P} 1-2 \mathrm{~A}^{*}$ constructs were incubated with purified calpain $1(\mathrm{C} 1)$ or 2 (C2) at $+25^{\circ} \mathrm{C}$ for $2 \mathrm{~h}$ or with viral proteases $2 \mathrm{~A}$ or $3 \mathrm{C}$ at $22{ }^{\circ} \mathrm{C}$ for $18 \mathrm{~h}$. Negative controls where no proteases were added were also included: ctrl1 and ctrl2 for calpain and viral protease reactions, respectively. (A) Schematic image of P1 and P1-2A* constructs. (B) Representative image of P1, P1-2A*, VP1, and VP3 bands revealed by immunolabeling western blots with antibodies against VP1 and VP3. (C-E) Quantification of P1, P1-2A*, VP1, and VP3 signal from Figure 3B. Data are presented as means \pm SEM from three separate experiments. Significance was determined with one-way ANOVA with Bonferroni's multiple comparisons test $\left({ }^{* *} p<0.01{ }^{* * *} p<0.001 ;{ }^{* * * *} p<0.0001\right.$; ns, non-significant).

\subsection{Calpain Activity is Concentration and Calcium Dependent and Can Be Prevented with Calpain Inhibitor} In Vitro

Next, we titrated the amount of calpain proteases in an in vitro assay with P1 construct and $2 \mathrm{mM}$ $\mathrm{CaCl}_{2}$. The results showed that VP1 was formed when 0.5 or 1 unit of calpain 1 or calpain 2 was used, respectively (Figure 4A). The processing was first seen as the appearance of a VP1+VP3 band, the intensity of which decreased as the amount of calpains was increased (Figure 4A). Interestingly, the VP1+VP3 band was already evident in the control sample, suggesting that host cell protease action in insect cell lysates could already promote the first cut within this in vitro reaction during $2 \mathrm{~h}$ at $+25^{\circ} \mathrm{C}$. The appearance of VP1+VP3 band in the control sample was dependent on $\mathrm{Ca}^{2+}$, since the band did not appear in the absence of $\mathrm{Ca}^{2+}$ (Figure 4A), suggesting that the cleavage was carried out by calcium-dependent calpain protease. In addition, the action of calpain $2(1 \mathrm{U})$ was blocked when the reaction was either done without $2 \mathrm{mM} \mathrm{CaCl}_{2}$ or when the $\mathrm{CaCl}_{2}$ was chelated with $4 \mathrm{mM}$ EGTA (Figure 4A). On the other hand, the cleavage action of calpain 1 was not affected when $\mathrm{Ca}^{2+}$ was not added, suggesting that the amount of $\mathrm{Ca}^{2+}$ in insect cell-derived P1 lysate was enough for the activity of this protease (Figure 4A). Also, surprisingly, the addition of EGTA did not prevent the cleavage action of calpain 1 leading to VP1 (Figure 4A). In contrast, EGTA addition led to the almost complete disappearance of the P1 band. What is behind this finding remains to be studied further. The difference of $\mathrm{Ca}^{2+}$ dependency for calpain 1 and 2 was further shown in an in vitro assay, where the amount of $\mathrm{CaCl}_{2}$ was titrated against 1 unit of calpain 1 or 2 (Figure $4 \mathrm{~B}$ ). The results showed that calpain 2 released VP1 from P1 only with $\mathrm{Ca}^{2+}$ concentrations higher than $0.2 \mathrm{mM}$ while calpain 1 released VP1 even without additional $\mathrm{CaCl}_{2}$.

Since both calpains 1 and 2 cleaved the viral P1 region, we wanted to verify whether the cleavage action of calpains can be prevented by carrying out an in vitro reaction, where purified calpains were incubated with the P1 polypeptide in the presence of calpain inhibitor. As above, the calpains without the presence of inhibitor produced cleavage products corresponding to VP1 and VP3, whereas in the presence of inhibitor, these cleavage products were not formed (Figure 4C,D). Altogether, these results further confirmed that the appearance of the bands corresponding to VP1 and VP3 proteins was due to action of calpains. 
A
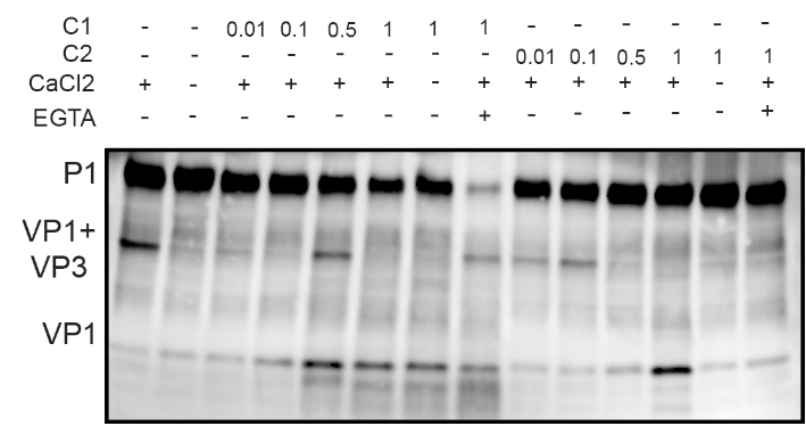

C
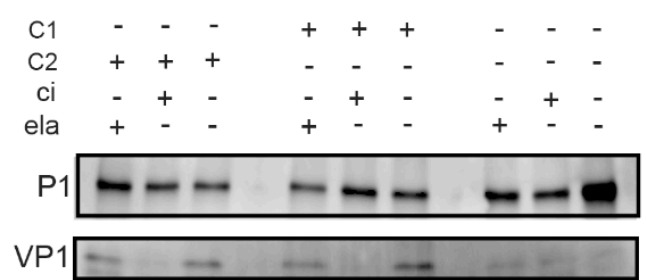

VP3

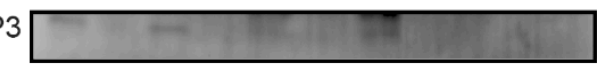

B

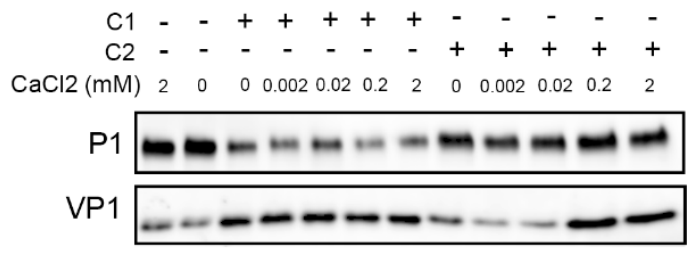

D
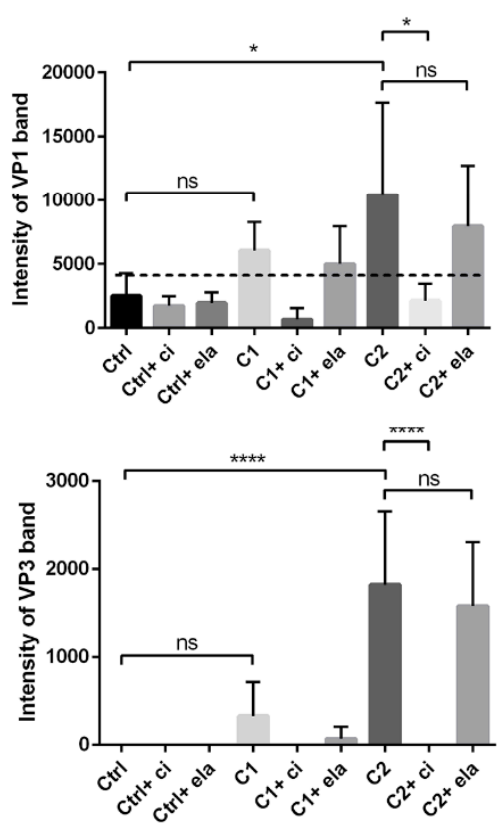

Figure 4. Effect of calpain concentration, calcium, and calpain inhibitor on calpain activity in vitro: (A) Calpain 1 (C1) or 2 (C2) were incubated with P1 polyprotein at $+25^{\circ} \mathrm{C}$ for $2 \mathrm{~h}$. The reactions included $2 \mathrm{mM} \mathrm{CaCl}_{2}$ and calpains with increasing catalytic activities: 0.01, 0.1, 0.5, or 1 unit. Also, samples without any proteases or $\mathrm{CaCl}_{2}$ or with $4 \mathrm{mM}$ EGTA were included. (B) Titration of $\mathrm{CaCl}_{2}$ against 1 unit of calpain 1 or 2 . The reactions were carried out as in Figure 4A. (C) The effect of calpain inhibitor (ci) or elastatinal (ela) on calpain activity during P1 processing: P1 was treated with 1 unit of calpain 1 (C1) or 2 (C2) in the presence or absence of $200 \mu \mathrm{M}$ calpain inhibitor (ci) or $250 \mu \mathrm{M}$ elastatinal (ela) for $2 \mathrm{~h}$ at $+25^{\circ} \mathrm{C}$. Representative images of P1, VP1, and VP3 bands. (D) Quantification of the VP1 and VP3 band intensities from Figure 4C: Data are presented as means \pm SEM from three separate experiments. Significance was determined with one-way ANOVA with Bonferroni's multiple comparisons test ${ }^{*} p<0.05 ; * * * * 00.0001 ; \mathrm{ns}$, nonsignificant).

\subsection{Calpains Cleave Specifically at the VP1-VP3 Cleavage Site}

Since we observed that calpains cleave P1 and produce VP1 and VP3 proteins, we concluded that calpains can cleave at around the site between VP0-VP3 and VP3-VP1. Since the sequence motif that is cut by calpains may differ from the viral proteases, we used synthetic peptide covering the VP3-VP1 cleavage site to study the cleavage site of calpains in more detail. This 30-amino-acid peptide (NH2-MLKDTPFIRQDNFYQ*GPVEESVERAMVRVA-COOH) also included the putative cleavage site of viral protease $3 \mathrm{C}$, indicated by asterisk. Unfortunately, a proper peptide corresponding to the cleavage site of VP0-VP3 could not be generated because of its low water solubility.

The peptide was used in mass spectrometry analysis to reveal the exact cleavage site for calpains. The peptide was incubated with purified calpains or 3C, and the cleavage site was revealed by analyzing the cleavage products produced by the proteases using SWATH-MS (Figure 5A). 
Based on the cleavage products (sequences) with the highest intensities, the results showed that the synthetic peptide was cleaved by calpains 1 and 2 from (NH2-) MLKDTPFIRQDNF/ YQGPVEESVERAMVRVA $(-\mathrm{COOH})$, whereas $3 \mathrm{C}$ cleaved this peptide within its reported cleavage site (NH2-) MLKDTPFIRQDNFYQ/GPVEESVERAMVRVA (-COOH) (Figure 5A).

Furthermore, we utilized this peptide in a competition assay to study whether the action of calpains and $3 \mathrm{C}$ can be inhibited in its excess. Purified calpains or $3 \mathrm{C}$ protease were incubated with P1 construct in the presence or absence of $100 \mu \mathrm{g}$ of the competing peptide. Both calpains 1 and 2 as well as $3 \mathrm{C}$ protease produced more VP1 in the absence of the peptide compared to the experiment in the presence of the peptide (Figure $5 \mathrm{~B}$ ), which suggests that these proteases cleave P1 at the VP3-VP1 cleavage site present in the competing peptide (Figure 5B). In conclusion, calpains 1 and 2 can specifically cleave between VP1 and VP3 and the cleavage site is two amino acids apart from the cleavage site used by $3 \mathrm{C}$ viral protease.

A
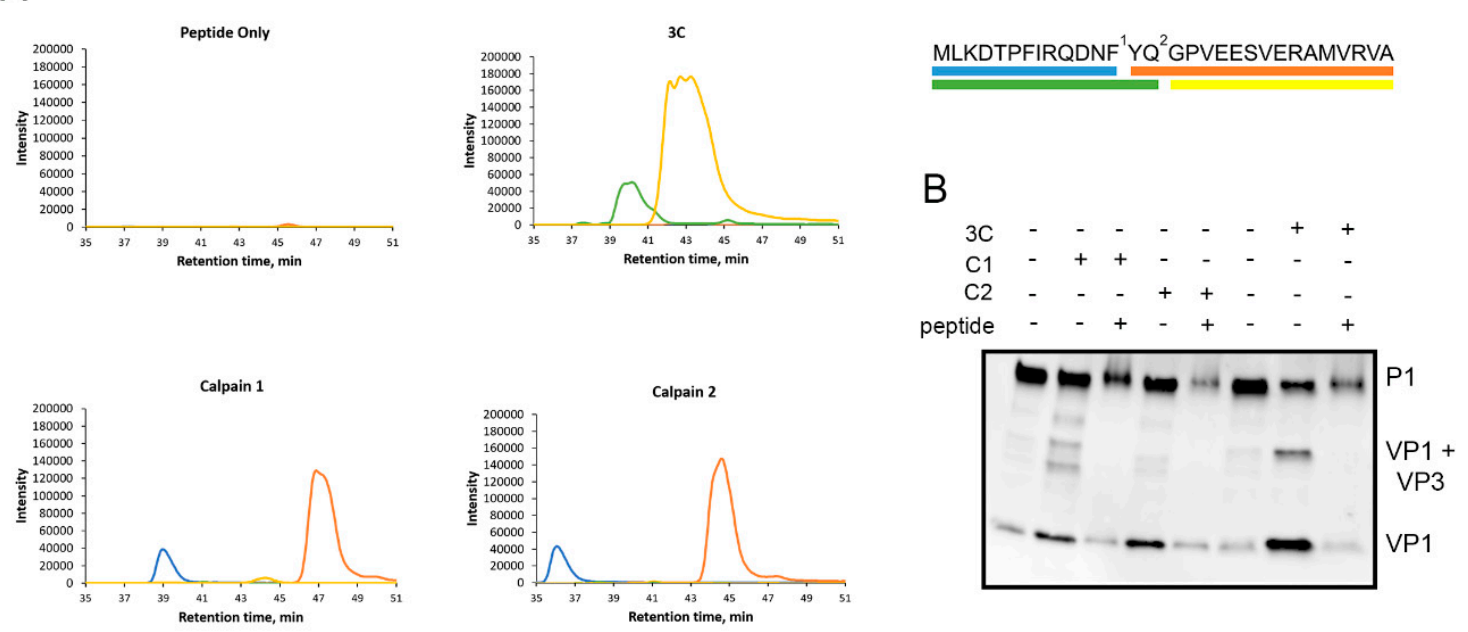

Figure 5. Calpains cleave specifically between VP1 and VP3. A 30-amino-acid artificial peptide around the VP1-VP3 cleavage site was used to study the cleavage site of calpains in more detail. (A) The peptide was incubated with calpain 1 or calpain 2 for $2 \mathrm{~h}$ at $+25^{\circ} \mathrm{C}$ or with $3 \mathrm{C}$ for $20 \mathrm{~h}$ at RT. Also, a control reaction with no proteases was included. The cleavage products were analyzed with SWATH-MS. The peaks correspond to different cleavage products, of which the sequences are color coded in the schematic image of the peptide on the right. Numbers 1 and 2 indicate the cleavage sites of calpains and 3C, respectively. (B) P1 construct was incubated with calpain 1 (C1) or 2 (C2) for $2 \mathrm{~h}$ at $+25^{\circ} \mathrm{C}$ or with $750 \mathrm{ng}$ of $3 \mathrm{C}$ protease for $17 \mathrm{~h}$ at $22^{\circ} \mathrm{C}$ with or without $100 \mu \mathrm{g}$ of the peptide. Also, controls with no proteases were included. Representative images of three experiments are shown.

\section{Discussion}

Earlier, we showed that calpain proteases of the host cell participate in enterovirus infection after entry and RNA release [8]. That study pinpointed the effect of calpains in the early translation/replication phase at $3 \mathrm{~h}$ p.i. when infection induces calpain activity, and it was the same time window during which the virus replication could be blocked with calpain inhibitors [8]. However, the molecular mechanism of calpain action during enterovirus infection remained unclear. Here, we show using in vitro assays that calcium-dependent neutral calpain proteases can cleave the P1 polyprotein of enterovirus B species and, as a result, produce VP1 and VP3 capsid proteins detected by western blotting. Moreover, the cleavage specificity of calpains at the VP3-VP1 interface was confirmed with mass spectrometry analysis and competition assay with a peptide, including the VP3-VP1 cleavage site. On the other hand, we show that calpains are not able to make the cleavage between P1 and 2A. 
Our results thus show that, in addition to viral proteases, the P1 can be cleaved by host cell calpain proteases and that this processing is specific for certain cleavage sites.

According to the dogma, the proteolytic processing of enteroviral polyprotein is thought to be carried out by viral proteases $2 \mathrm{~A}$ and $3 \mathrm{C}$ and the precursor $3 \mathrm{CD}$ protein [14,31]. 2A protease makes the first autocatalytic cleavage already during translation between VP1 and itself. The rest of the cleavages are then supposed to be carried out either by 3C or 3CD. Lawson and Semler (1992) showed in their earlier study in vitro that, as $\mathrm{P} 1$ precursor was visible already at 25 min during in vitro translation, there was a delay in the processing until $70 \mathrm{~min}$, although 3CD was detected as early as $50 \mathrm{~min}$ [32]. In infected cells, according to their metabolic labeling, $3 C$ and $3 C D$ were more active when enriched in the membranous fraction while P1 precursor and its processing occurred very efficiently also in the soluble fraction [32]. Perhaps the P1, which is found close to the replication membranes, are processed by $3 \mathrm{C}$ or $3 \mathrm{CD}$, but the $\mathrm{P} 1$ found in the soluble fraction may be preferentially processed by calpain proteases readily available in the same pool. Whether calpain proteases truly function in infected cells and take part in polyprotein processes remains to be shown.

Viral proteases and calpains belong to the class of cysteine proteases and are both present in infected cells. Due to difficulties in differentiating calpain from viral protease action, the possible participation of calpains in polyprotein processing is difficult to demonstrate. The use of calpain inhibitors in virus infection assays is challenging due to cross-reactivity with viral proteases $2 \mathrm{~A}$ and $3 \mathrm{C}$, as has been shown for $2 \mathrm{~A}$ by others as well [30]. Therefore, we wanted to study the action of calpains separately from viral proteases and to study the direct effect of purified calpain proteases on viral polyprotein processing. We produced the P1 region of CVB1 polyprotein in baculovirus insect cell expression system and incubated it with the purified calpains 1 and 2 in vitro. These studies and the mass spectrometry analysis unequivocally demonstrated that calpains could cleave at the polyprotein between VP3 and VP1 using cleavage sites differing with only two amino acids to that utilized by enteroviral protease 3C. However, further studies are needed to verify if the capsid proteins produced by calpains could be used in the production of pentamers and subsequently in the assembly of infectious virions. Interestingly, it has been shown earlier with foot-and-mouth disease virus that even longer amino acid segments can be attached to VP1 without hindrance in capsid production [33]. They showed that empty capsids and infectious virions were produced even if the cleavage between VP1 and 2A was prevented. This further suggests that the two-amino-acid difference in the cleavage site of calpains compared to $3 \mathrm{C}$ does not hinder capsid production. However, this remains to be shown.

Thus, as a proof of principle, we showed that calpains can process enterovirus polyprotein in vitro. Does this happen in cells as well? It has been shown earlier that enteroviruses affect the calcium homeostasis during infection by releasing calcium stores from ER and by increasing the permeability of plasma membrane, resulting in the increase of cytosolic calcium concentration [34,35]. Therefore, changes in calcium homeostasis due to virus infection may trigger calpain activation. Furthermore, Bozym et al. showed that the changes in calcium concentration during CVB3 infection occurred at 2-3 h p.i. [24], and our earlier results showed that calpain activity increased at 3-4 h p.i. [8]. Altogether, these earlier studies supported the idea that calpains get activated after virus entry during the first steps of translation/replication. Furthermore, our earlier studies using calpain-specific siRNAs more specifically showed that calpains themselves were needed for infection [8]. Interestingly, Bozym et al. found less effect on CVB3 infection with calpain siRNAs, which could possibly be due to the ineffectiveness of the siRNAs, leading to only a partial silencing of calpain genes [24]. Also, in our earlier studies, calpain siRNAs decreased EV1 infection but did not block it completely [8]. In addition to calpains 1 and 2, there are 13 other calpains that possibly contribute to the proteolytic processing, thus making it difficult to completely get rid of calpain action in the cells using siRNAs.

Calpain proteases are very abundant in cells, and their activation is controlled by calcium concentration, a process in which enteroviruses also contribute to. In vitro assays have shown that the calcium requirement of calpain 1 and 2 differ: calpain 1 needs micromolar whereas calpain 2 needs millimolar concentrations of calcium [20]. The calpain activation, especially in vivo, is still 
under investigation to understand how the proteases are activated in cells, where such high calcium concentrations do not exist. However, couple different mechanisms have been suggested: (1) On one hand, increased calcium concentration in the cytoplasm may trigger an autolysis in the N-terminal region of both catalytic and regulatory subunits, resulting in conformational change and finally calpain activation [36,37]. The autolysis may then increase calpain turnover, sensitivity to calcium and substrate accessibility. (2) On the other hand, increased calcium concentration may promote the translocation of calpains to membranes, where the calpains are activated without autolysis in the presence of protein activators and other factors such as phospholipids [38-42]. The presence of activators may decrease the calcium requirement to physiological levels, and translocation to membranes may especially promote membrane-associated proteins as substrates. Additionally, it has been suggested that calpain 1 activation in the presence of micromolar calcium concentration could trigger a cascade where also calpain 2 is activated even with micromolar calcium level [43]. In our in vitro assays, we saw that calpain 2 released more VP1 and VP3 proteins from enterovirus polyprotein compared to calpain 1. However, mass spectrometry analysis showed that both calpains were able to cleave at the VP1-VP3 cleavage site in the same location. The elevated calcium concentrations in cells, which trigger calpain activation, do not resemble the in vitro conditions, and hence, the assessment of calpain isoform preference for enterovirus polyprotein processing from in vitro assays is difficult.

There are a few studies which connect calpain proteases to enterovirus infection after cell entry during trafficking of CVB3-containing vesicles into the perinuclear region [23] for CVB-induced necrosis [24] or for autophagy [25,44]. Most of these studies were carried out using calpain inhibitors, which, as we have shown, might be problematic due to the cross-reactivity with viral proteases. It is difficult to distinguish the effect of the inhibitor on calpains or viral proteases in infection assays, which may confound the outcomes in cellular responses and the interpretation of the results. In addition, there are differences between enterovirus serotypes: we have shown earlier that, in contrast to coxsackie B viruses, EV1 does not need autophagosomes in its infection [8,9]. This was shown using an autophagosomal marker LC3, of which the overexpression did not increase EV1 infection and the amount or size of the LC3 structures did not increase during EV1 infection [8,9]. Thus, our earlier study suggests that, at least during EV1 infection, the role of calpains is not related to autophagy. On the other hand, taking into account the abundancy of calpains in cells and that their activity is mainly regulated by calcium concentration, calpains may play a role in multiple steps during the infection. In addition to enteroviruses, calpains have also been associated with other virus infections, such as influenza, herpesvirus, chikungunya, and other picornaviruses [45-50]. Particularly, processing of a viral protein by calpains has been shown with another RNA virus, Hepatitis $C$ virus [51]. Since calpain activity has been shown to be involved in the infections of several viruses, calpains have been suggested as potential targets for antiviral therapies. Our previous and current results suggest that calpain inhibition could also be targeted against enteroviral infections and diseases such as myocarditis, meningitis, or sepsis-like syndrome of infants [2-4,52-55]. It can be speculated that, during evolution, enteroviruses have adapted to using the readily available and active cellular proteases to promote their infection. It may well be that, along time, calpains have become an important backup system in polyprotein processing, while the viral proteases have promoted the infection also by other means, such as cleaving host cell factors related to apoptosis, immune responses, and cellular translation [10]. It has been shown that enteroviruses may stay silent or persistent in tissues for long periods without causing much damage or cell death $[3,56,57]$. In such circumstances, the viral proteases are likely to be downregulated not to promote apoptosis and cell death, while calpains may still help the polyprotein to be processed further.

The extended $\mathrm{P} 1$ polyprotein containing mutated 2A suggested that 2A protease is needed in cis to execute the first cleavage between P2-P3 and P1. This action could not be executed by calpains or by $2 \mathrm{~A}$ in trans. In addition, the action of $2 \mathrm{~A}$ could not be inhibited by the specific $2 \mathrm{~A}$ inhibitor elastatinal during infection of EV1, CVA9, or CVB1 although that inhibitor could inhibit 2A action against the cellular targets in trans. Probably, elastatinal was not able to bind to 2A before 2A was released from 
the polyprotein and, hence, could not prevent cis action of 2A and, further, the infection. The low inhibitory effect of elastatinal has also been shown with poliovirus earlier [30]. Whether calpains can cleave nonstructural proteins from other $3 \mathrm{C} / 3 \mathrm{CD}$ specific cleavage sites at the $\mathrm{P} 2-\mathrm{P} 3$ region remains to be studied.

\section{Conclusions}

Our results demonstrate that calpain proteases can proteolytically process enterovirus polyprotein in vitro, resulting in the release of capsid proteins. Furthermore, the high cross-reactivity of calpain inhibitors with viral proteases observed in this study highlights their potential also as future antivirals.

Author Contributions: Conceptualization, V.M., M.L., M.M.H., O.H.L., and V.P.H.; methodology, M.L., M.M.H, V.M., and O.H.L.; validation, M.L., V.M., M.M.H., and J.A.E.M.; formal analysis, M.L. and J.A.E.M.; investigation, M.L., M.M.H., and J.A.E.M.; resources, V.M. and V.P.H.; data curation, M.L., M.M.H., and J.A.E.M.; writing-original draft preparation, V.M. and M.L.; writing—review and editing, V.M., M.L., M.M.H., O.H.L., V.P.H., and J.A.E.M; visualization, M.L., J.A.E.M., and V.P.H.; supervision, V.M., O.H.L., and V.P.H.; project administration, V.M., O.H.L., and V.P.H.; funding acquisition, V.M., M.M.H., and V.P.H.

Funding: This research was funded by Jane and Aatos Erkko foundation and Academy of Finland, grant number 1309455.

Acknowledgments: The authors acknowledge the Tampere facility of Protein Services and the Tampere Mass Spectrometry Facility for their services. We acknowledge Biocenter Finland for infrastructure support. We also thank Niko Kangasniemi for preliminary studies and Tino Kantoluoto for technical assistance.

Conflicts of Interest: The authors declare no conflict of interest. The funders had no role in the design of the study; in the collection, analyses, or interpretation of data; in the writing of the manuscript; or in the decision to publish the results.

\section{References}

1. Tapparel, C.; Siegrist, F.; Petty, T.J.; Kaiser, L. Picornavirus and Enterovirus Diversity with Associated Human Diseases. Infect. Genet. Evol. 2013, 14, 282-293. [CrossRef] [PubMed]

2. Gaaloul, I.; Riabi, S.; Harrath, R.; Hunter, T.; Hamda, K.B.; Ghzala, A.B.; Huber, S.; Aouni, M. Coxsackievirus B Detection in Cases of Myocarditis, Myopericarditis, Pericarditis and Dilated Cardiomyopathy in Hospitalized Patients. Mol. Med. Rep. 2014, 10, 2811-2818. [CrossRef] [PubMed]

3. Bouin, A.; Gretteau, P.A.; Wehbe, M.; Renois, F.; N'Guyen, Y.; Leveque, N.; Vu, M.N.; Tracy, S.; Chapman, N.M.; Bruneval, P.; et al. Enterovirus Persistence in Cardiac Cells of Patients with Idiopathic Dilated Cardiomyopathy is Linked to 5' Terminal Genomic RNA-Deleted Viral Populations with Viral-Encoded Proteinase Activities. Circulation 2019, 139, 2326-2338. [CrossRef] [PubMed]

4. Verma, N.A.; Zheng, X.T.; Harris, M.U.; Cadichon, S.B.; Melin-Aldana, H.; Khetsuriani, N.; Oberste, M.S.; Shulman, S.T. Outbreak of Life-Threatening Coxsackievirus B1 Myocarditis in Neonates. Clin. Infect. Dis. 2009, 49, 759-763. [CrossRef] [PubMed]

5. Oikarinen, S.; Tauriainen, S.; Hober, D.; Lucas, B.; Vazeou, A.; Sioofy-Khojine, A.; Bozas, E.; Muir, P.; Honkanen, H.; Ilonen, J.; et al. Virus Antibody Survey in Different European Populations Indicates Risk Association between Coxsackievirus B1 and Type 1 Diabetes. Am. Diabetes Assoc. 2014, 63, 655-662. [CrossRef] [PubMed]

6. Sioofy-Khojine, A.B.; Lehtonen, J.; Nurminen, N.; Laitinen, O.H.; Oikarinen, S.; Huhtala, H.; Pakkanen, O.; Ruokoranta, T.; Hankaniemi, M.M.; Toppari, J.; et al. Coxsackievirus B1 Infections are Associated with the Initiation of Insulin-Driven Autoimmunity that Progresses to Type 1 Diabetes. Diabetologia 2018, 61, 1193-1202. [CrossRef]

7. Laitinen, O.H.; Honkanen, H.; Pakkanen, O.; Oikarinen, S.; Hankaniemi, M.M.; Huhtala, H.; Ruokoranta, T.; Lecouturier, V.; Andre, P.; Harju, R.; et al. Coxsackievirus B1 is Associated with Induction of Beta-Cell Autoimmunity that Portends Type 1 Diabetes. Am. Diabetes Assoc. 2014, 63, 446-455. [CrossRef]

8. Upla, P.; Marjomaki, V.; Nissinen, L.; Nylund, C.; Waris, M.; Hyypia, T.; Heino, J. Calpain 1 and 2 are Required for RNA Replication of Echovirus 1. J. Virol. 2008, 82, 1581-1590. [CrossRef] 
9. Rintanen, N.; Karjalainen, M.; Alanko, J.; Paavolainen, L.; Maki, A.; Nissinen, L.; Lehkonen, M.; Kallio, K.; Cheng, R.H.; Upla, P.; et al. Calpains Promote $\alpha 2 \beta 1$ Integrin Turnover in Nonrecycling Integrin Pathway. Mol. Biol. Cell 2012, 23, 448-463. [CrossRef]

10. Laitinen, O.H.; Svedin, E.; Kapell, S.; Nurminen, A.; Hytonen, V.P.; Flodstrom-Tullberg, M. Enteroviral Proteases: Structure, Host Interactions and Pathogenicity. Rev. Med. Virol. 2016, 26, 251-267. [CrossRef]

11. Palmenberg, A.C. Proteolytic Processing of Picornaviral Polyprotein. Annu. Rev. Microbiol. 1990, 44, $603-623$. [CrossRef] [PubMed]

12. Sommergruber, W.; Zorn, M.; Blaas, D.; Fessl, F.; Volkmann, P.; Maurer-Fogy, I.; Pallai, P.; Merluzzi, V.; Matteo, M.; Skern, T. Polypeptide 2A of Human Rhinovirus Type 2: Identification as a Protease and Characterization by Mutational Analysis. Virology 1989, 169, 68-77. [CrossRef]

13. Toyoda, H.; Nicklin, M.J.; Murray, M.G.; Anderson, C.W.; Dunn, J.J.; Studier, F.W.; Wimmer, E. A Second Virus-Encoded Proteinase Involved in Proteolytic Processing of Poliovirus Polyprotein. Cell 1986, 45, 761-770. [CrossRef]

14. Nicklin, M.J.; Krausslich, H.G.; Toyoda, H.; Dunn, J.J.; Wimmer, E. Poliovirus Polypeptide Precursors: Expression in Vitro and Processing by Exogenous 3C and 2A Proteinases. Proc. Natl. Acad. Sci. USA 1987, 84, 4002-4006. [CrossRef] [PubMed]

15. Ypma-Wong, M.F.; Dewalt, P.G.; Johnson, V.H.; Lamb, J.G.; Semler, B.L. Protein 3CD is the Major Poliovirus Proteinase Responsible for Cleavage of the P1 Capsid Precursor. Virology 1988, 166, 265-270. [CrossRef]

16. Sun, D.; Chen, S.; Cheng, A.; Wang, M. Roles of the Picornaviral 3C Proteinase in the Viral Life Cycle and Host Cells. Viruses 2016, 8, 82. [CrossRef]

17. Seipelt, J.; Guarne, A.; Bergmann, E.; James, M.; Sommergruber, W.; Fita, I.; Skern, T. The Structures of Picornaviral Proteinases. Virus Res. 1999, 62, 159-168. [CrossRef]

18. Ono, Y.; Sorimachi, H. Calpains: An Elaborate Proteolytic System. Biochim. Biophys. Acta 2012, 1824, $224-236$. [CrossRef]

19. Moldoveanu, T.; Campbell, R.L.; Cuerrier, D.; Davies, P.L. Crystal Structures of Calpain-E64 and -Leupeptin Inhibitor Complexes Reveal Mobile Loops Gating the Active Site. J. Mol. Biol. 2004, 343, 1313-1326. [CrossRef]

20. Goll, D.E.; Thompson, V.F.; Li, H.; Wei, W.; Cong, J. The Calpain System. Physiol. Rev. 2003, 83, 731-801. [CrossRef]

21. Sakai, K.; Akanuma, H.; Imahori, K.; Kawashima, S. A Unique Specificity of a Calcium Activated Neutral Protease Indicated in Histone Hydrolysis. J. Biochem. 1987, 101, 911-918. [CrossRef] [PubMed]

22. Stabach, P.R.; Cianci, C.D.; Glantz, S.B.; Zhang, Z.; Morrow, J.S. Site-Directed Mutagenesis of Alpha II Spectrin at Codon 1175 Modulates its Mu-Calpain Susceptibility. Biochemistry 1997, 36, 57-65. [CrossRef] [PubMed]

23. Bozym, R.A.; Morosky, S.A.; Kim, K.S.; Cherry, S.; Coyne, C.B. Release of Intracellular Calcium Stores Facilitates Coxsackievirus Entry into Polarized Endothelial Cells. PLoS Pathog. 2010, 6. [CrossRef] [PubMed]

24. Bozym, R.A.; Patel, K.; White, C.; Cheung, K.H.; Bergelson, J.M.; Morosky, S.A.; Coyne, C.B. Calcium Signals and Calpain-Dependent Necrosis are Essential for Release of Coxsackievirus B from Polarized Intestinal Epithelial Cells. Mol. Biol. Cell 2011, 22, 3010-3021. [CrossRef] [PubMed]

25. Yoon, S.Y.; Ha, Y.E.; Choi, J.E.; Ahn, J.; Lee, H.; Kweon, H.S.; Lee, J.Y.; Kim, D.H. Coxsackievirus B4 Uses Autophagy for Replication After Calpain Activation in Rat Primary Neurons. J. Virol. 2008, 82, 11976-11978. [CrossRef]

26. Laitinen, O.H.; Svedin, E.; Kapell, S.; Hankaniemi, M.M.; Larsson, P.G.; Domsgen, E.; Stone, V.M.; Maatta, J.A.E.; Hyoty, H.; Hytonen, V.P.; et al. New Coxsackievirus 2A (Pro) and 3C (Pro) Protease Antibodies for Virus Detection and Discovery of Pathogenic Mechanisms. J. Virol. Methods 2018, 255, 29-37. [CrossRef]

27. Feng, Q.; Langereis, M.A.; Lork, M.; Nguyen, M.; Hato, S.V.; Lanke, K.; Emdad, L.; Bhoopathi, P.; Fisher, P.B.; Lloyd, R.E.; et al. Enterovirus 2Apro Targets MDA5 and MAVS in Infected Cells. J. Virol. 2014, 88, 3369-3378. [CrossRef]

28. Marjomaki, V.; Pietiainen, V.; Matilainen, H.; Upla, P.; Ivaska, J.; Nissinen, L.; Reunanen, H.; Huttunen, P.; Hyypia, T.; Heino, J. Internalization of Echovirus 1 in Caveolae. J. Virol. 2002, 76, 1856-1865. [CrossRef]

29. Vahatupa, M.; Nattinen, J.; Jylha, A.; Aapola, U.; Kataja, M.; Koobi, P.; Jarvinen, T.A.H.; Uusitalo, H.; Uusitalo-Jarvinen, H. SWATH-MS Proteomic Analysis of Oxygen-Induced Retinopathy Reveals Novel Potential Therapeutic Targets. Invest. Ophthalmol. Vis. Sci. 2018, 59, 3294-3306.

30. Molla, A.; Hellen, C.U.; Wimmer, E. Inhibition of Proteolytic Activity of Poliovirus and Rhinovirus 2A Proteinases by Elastase-Specific Inhibitors. J. Virol. 1993, 67, 4688-4695. 
31. Krausslich, H.G.; Nicklin, M.J.; Lee, C.K.; Wimmer, E. Polyprotein Processing in Picornavirus Replication. Biochimie 1988, 70, 119-130. [CrossRef]

32. Lawson, M.A.; Semler, B.L. Alternate Poliovirus Nonstructural Protein Processing Cascades Generated by Primary Sites of 3C Proteinase Cleavage. Virology 1992, 191, 309-320. [CrossRef]

33. Gullberg, M.; Polacek, C.; Botner, A.; Belsham, G.J. Processing of the VP1/2A Junction is Not Necessary for Production of Foot-and-Mouth Disease Virus Empty Capsids and Infectious Viruses: Characterization of “Self-Tagged" Particles. J. Virol. 2013, 87, 11591-11603. [CrossRef] [PubMed]

34. van Kuppeveld, F.J.; Hoenderop, J.G.; Smeets, R.L.; Willems, P.H.; Dijkman, H.B.; Galama, J.M.; Melchers, W.J. Coxsackievirus Protein 2B Modifies Endoplasmic Reticulum Membrane and Plasma Membrane Permeability and Facilitates Virus Release. EMBO J. 1997, 16, 3519-3532. [CrossRef] [PubMed]

35. Aldabe, R.; Irurzun, A.; Carrasco, L. Poliovirus Protein 2BC Increases Cytosolic Free Calcium Concentrations. J. Virol. 1997, 71, 6214-6217. [PubMed]

36. Imajoh, S.; Kawasaki, H.; Suzuki, K. Limited Autolysis of Calcium-Activated Neutral Protease (CANP): Reduction of the $\mathrm{Ca}^{2+}$-Requirement is due to the NH2-Terminal Processing of the Large Subunit. J. Biochem. 1986, 100, 633-642. [CrossRef]

37. Inomata, M.; Kasai, Y.; Nakamura, M.; Kawashima, S. Activation Mechanism of Calcium-Activated Neutral Protease. Evidence for the Existence of Intramolecular and Intermolecular Autolyses. J. Biol. Chem. 1988, 263, 19783-19787.

38. Molinari, M.; Anagli, J.; Carafoli, E. Ca ${ }^{2+}$-Activated Neutral Protease is Active in the Erythrocyte Membrane in its Nonautolyzed 80-kDa Form. J. Biol. Chem. 1994, 269, 27992-27995.

39. Suzuki, K.; Imajoh, S.; Emori, Y.; Kawasaki, H.; Minami, Y.; Ohno, S. Calcium-Activated Neutral Protease and its Endogenous Inhibitor. Activation at the Cell Membrane and Biological Function. FEBS Lett. 1987, 220, 271-277. [CrossRef]

40. Melloni, E.; Michetti, M.; Salamino, F.; Pontremoli, S. Molecular and Functional Properties of a Calpain Activator Protein Specific for Mu-Isoforms. J. Biol. Chem. 1998, 273, 12827-12831. [CrossRef]

41. Pontremoli, S.; Melloni, E.; Michetti, M.; Salamino, F.; Sparatore, B.; Horecker, B.L. An Endogenous Activator of the Ca2+-Dependent Proteinase of Human Neutrophils that Increases its Affinity for Ca ${ }^{2+}$. Proc. Natl. Acad. Sci. USA 1988, 85, 1740-1743. [CrossRef] [PubMed]

42. Saido, T.C.; Mizuno, K.; Suzuki, K. Proteolysis of Protein Kinase C by Calpain: Effect of Acidic Phospholipids. Biomed. Biochim. Acta 1991, 50, 485-489. [PubMed]

43. Tompa, P.; Baki, A.; Schad, E.; Friedrich, P. The Calpain Cascade. Mu-Calpain Activates M-Calpain. J. Biol. Chem. 1996, 271, 33161-33164. [CrossRef] [PubMed]

44. Li, M.; Wang, X.; Yu, Y.; Yu, Y.; Xie, Y.; Zou, Y.; Ge, J.; Peng, T.; Chen, R. Coxsackievirus B3-Induced Calpain Activation Facilitates the Progeny Virus Replication Via a Likely Mechanism Related with both Autophagy Enhancement and Apoptosis Inhibition in the Early Phase of Infection: An in Vitro Study in H9c2 Cells. Virus Res. 2014, 179, 177-186. [CrossRef] [PubMed]

45. Karpe, Y.A.; Pingale, K.D.; Kanade, G.D. Activities of Proteasome and M-Calpain are Essential for Chikungunya Virus Replication. Virus Genes 2016, 52, 716-721. [CrossRef] [PubMed]

46. Howe, C.L.; LaFrance-Corey, R.G.; Mirchia, K.; Sauer, B.M.; McGovern, R.M.; Reid, J.M.; Buenz, E.J. Neuroprotection Mediated by Inhibition of Calpain during Acute Viral Encephalitis. Sci. Rep. 2016, 6. [CrossRef] [PubMed]

47. Zheng, K.; Xiang, Y.; Wang, Q.; Jin, F.; Chen, M.; Ma, K.; Ren, Z.; Wang, Y. Calcium-Signal Facilitates Herpes Simplex Virus Type 1 Nuclear Transport through Slingshot 1 and Calpain-1 Activation. Virus Res. 2014, 188, 32-37. [CrossRef]

48. Blanc, F.; Furio, L.; Moisy, D.; Yen, H.L.; Chignard, M.; Letavernier, E.; Naffakh, N.; Mok, C.K.; Si-Tahar, M. Targeting Host Calpain Proteases Decreases Influenza A Virus Infection. Am. J. Physiol.-Lung Cell. Mol. Physiol. 2016, 310, 689. [CrossRef]

49. DeBiasi, R.L.; Edelstein, C.L.; Sherry, B.; Tyler, K.L. Calpain Inhibition Protects Against Virus-Induced Apoptotic Myocardial Injury. J. Virol. 2001, 75, 351-361. [CrossRef]

50. Debiasi, R.L.; Squier, M.K.; Pike, B.; Wynes, M.; Dermody, T.S.; Cohen, J.J.; Tyler, K.L. Reovirus-Induced Apoptosis is Preceded by Increased Cellular Calpain Activity and is Blocked by Calpain Inhibitors. J. Virol. 1999, 73, 695-701. 
51. Kalamvoki, M.; Mavromara, P. Calcium-Dependent Calpain Proteases are Implicated in Processing of the Hepatitis C Virus NS5A Protein. J. Virol. 2004, 78, 11865-11878. [CrossRef] [PubMed]

52. Bryant, P.A.; Tingay, D.; Dargaville, P.A.; Starr, M.; Curtis, N. Neonatal Coxsackie B Virus Infection-a Treatable Disease? Eur. J. Pediatr. 2004, 163, 223-228. [CrossRef] [PubMed]

53. Chiou, C.C.; Liu, W.T.; Chen, S.J.; Soong, W.J.; Wu, K.G.; Tang, R.B.; Hwang, B. Coxsackievirus B1 Infection in Infants Less than 2 Months of Age. Am. J. Perinatol. 1998, 15, 155-159. [CrossRef] [PubMed]

54. Muehlenbachs, A.; Bhatnagar, J.; Zaki, S.R. Tissue Tropism, Pathology and Pathogenesis of Enterovirus Infection. J. Pathol. 2015, 235, 217-228. [CrossRef]

55. Joo, C.H.; Ahn, J.; Seo, I.; Kim, Y.K.; Kim, D.; Hong, H.; Lee, H. Characterization of Nonpolio Enteroviruses Recovered from Patients with Aseptic Meningitis in Korea. Intervirology 2005, 48, 97-103. [CrossRef] [PubMed]

56. Alidjinou, E.K.; Sane, F.; Engelmann, I.; Geenen, V.; Hober, D. Enterovirus Persistence as a Mechanism in the Pathogenesis of Type 1 Diabetes. Discov. Med. 2014, 18, 273-282.

57. Flynn, C.T.; Kimura, T.; Frimpong-Boateng, K.; Harkins, S.; Whitton, J.L. Immunological and Pathological Consequences of Coxsackievirus RNA Persistence in the Heart. Virology 2017, 512, 104-112. [CrossRef]

(C) 2019 by the authors. Licensee MDPI, Basel, Switzerland. This article is an open access article distributed under the terms and conditions of the Creative Commons Attribution (CC BY) license (http://creativecommons.org/licenses/by/4.0/). 